\title{
DISTRIBUTION AND QUANTITATIVE CHANGES OF MAST CELLS IN GUINEA PIGS LUNG IN OVALBUMIN-INDUCED ALLERGIC INFLAMMATION
}

\author{
*S.S. Popko, V.M. Yevtushenko \\ ZAPORIZHZHIA STATE MEDICAL UNIVERSITY, ZAPORIZHZHIA, UKRAINE
}

Background. One of the most important cells in local immunity in lung are mast cells. They are involved in both innate and adaptive immune responses to inhaled allergens. The question of distribution of these both cell types in guinea pig lung in case of experimental allergic inflammation in most aspects remains open.

Objective. The aim of this research is to study the distribution and quantitative changes of mast cells in lung of guinea pigs in ovalbumin-induced allergic inflammation.

Methods. the lungs of 48 male guinea pigs have been studied using histological, morphometric and statistical methods in cases of experimental ovalbumin-induced allergic inflammation. The total number of mucosa related must cells and perivascular mast cells in guinea pig lungs were counted.

Results. It has been established that mucosa related mast cells are normally more abundant in guinea pigs lung than perivascular ones. Maximum increase in a number of mucosa related mast cells was revealed in the early period of allergic inflammation, as evidenced by maximum increase coefficient of 1.4 in the $1^{\text {st }}$ experimental group, compare to the control $\left(P^{* * * *}<0.05\right)$. However, maximum increase in number of perivascular mast cells in 5 times was found during the late period of allergic inflammation in the $4^{\text {th }}$ experimental group $\left(P^{* * *}<0.05\right)$.

Conclusion. Experimental sensitization and challenge with ovalbumin leads to statistically significant increase in average number of both types of mast cells but predominantly the latter ones. It has been proved that cells dynamics is multidirectional.

KEYWORDS: mucosa related must cell, perivascular mast cell, lung, guinea pig, allergic inflammation.

\section{Introduction}

Mast cells are present in vascularized tissues of almost all organs except the central nervous system and the retina. Derived from pluripotent red bone marrow stem cells, they differentiate in connective tissue from their progenitor cells under the influence of c-Kit ligand (CD117) in the presence of growth factors and various cytokines realized by the connective tissue microenvironment of the organs in which they are located and function $[1,2]$. The cytoplasm of mature mast cells contains 50-200 granules of inflammatory mediators, such as histamine, heparin, numerous cytokines, chondroitin sulphate, and neutral proteases (chymase and tryptase), provided mechanisms to increase the permeability of the microvessel wall and perivascular connective tissue, angiogenesis [3]. They regulate the inflammatory process in the connective tissue, influencing the permeability of the vascular wall

*Corresponding author: Svitlana S. Popko, PhD, Associate Professor of the Department of Histology, Cytology and Embryology, Zaporizhzhia State Medical University, Zaporizhzhia, 69035, Ukraine.E-mail:kluchkosv@gmail.com and the amorphous component of the intercellular substance. In addition, they are involved in implementation of allergic reactions due to the presence of FccRI receptors on immunoglobulins type $\mathrm{E}$ on their plasmalemma. On the other hand, microvessel endothelial cells, secreting adhesion molecules VCAM-1, ICAM-1 and ELAM-1, initiate migration of mast cells precursors from the peripheral bloodstream into the tissue where the inflammatory process takes place [4].

It is established that in lung of human and BALB/c mice in normal physiological conditions the number of mast cell progenitors is insignificant, but in cases of antigen-induced inflammation under the influence of a $4 \beta 7$ integrins, VCAM-1 and CXCR2 they actively migrate to lung tissue [5]. Mast cells, located in different parts of the lungs and respiratory tract, have excellent histochemical properties and express different mediators. Two phenotypes of mast cells have been studied in lung of human and small mammals: mucosa related mast cells (synthesize only tryptase) and perivascular mast cells (synthesize tryptase, chymase, and carboxypep- 
tidase), with the predominance of the latter. Previous studies have postulated hyperplasia of both mast cell phenotypes in the human lung with development of allergic inflammatory process. In contrast to human, BALB/c mice during the allergic inflammatory process showed the increase in the number of mucosa related mast cells only, without affecting the dynamics and differentiation of resident perivascular mast cells $[4,5]$. Very little is known about mast cells and their distribution in guinea pigs lung in case of experimental antigen sensitization, although the high sensitivity and susceptibility of their respiratory system to allergic and infectious diseases makes them a useful experimental model of pathological conditions such as bronchial asthma and tuberculosis [6].

Therefore, the aim of the research is to study distribution and quantitative changes of mast cells in lung of guinea pigs in ovalbumininduced allergic inflammation.

\section{Methods}

The object of the experimental study was lung removed from 48 sexually mature male guinea pigs, kept in standard conditions of the vivarium of the Zaporizhzhya State Medical University. Experiments on animals were carried out in accordance with the provisions of the European Convention for the Protection of Vertebrate Animals Used for Experimental and Other Scientific Purposes (Strasbourg, 1986), Council Directives 86/609 / EEC (1986), Laws of Ukraine № 3447-IV “On the protection of animals from cruel treatment, general ethical principles of animal experiments", approved by the First National Congress of Ukraine on Bioethics (2001). Induction of allergic airway inflammation was carried out by subcutaneous sensitization and subsequent aeroallergization with ovalbumin (OVA) [7]. On days 1, 7, 14 of the experiment, guinea pigs were sensitized: subcutaneous injection into the interscapular region of $0.5 \mathrm{mg}$ OVA (Sigma Chemical Co., USA) together with an adjuvant - aluminium hydroxide, $10 \mathrm{mg}$ (AlumVax Hydroxide vaccine adjuvant, OZ Biosciences, France) diluted in $1 \mathrm{ml}$ of saline. From 21 to 28 days of the experiment, the animals were aeroallergized OVA at the dose of $10 \mathrm{mg} / \mathrm{ml}$ of saline for $15 \mathrm{~min} /$ day using an LD-211C compressor inhaler (Little Doctor International, Singapore) in an inhalation chamber. The animals were divided into 6 groups ( 8 animals in each group) for investigations. The first four groups were animals, sensitized and challenged OVA, withdrawn from the experiment, respectively, on the $23^{\text {rd }}, 30^{\text {th }}, 36^{\text {th }}$ and $44^{\text {th }}$ days after its start; the $5^{\text {th }}$ group - control, the animals were injected subcutaneously with 1 $\mathrm{ml}$ of saline and inhaled with saline; the $6^{\text {th }}$ intact group. For the purpose of rational presentation of the obtained data and their interpretation, we conditionally distinguish the early $\left(23^{\text {rd }}, 30^{\text {th }}\right.$ days of the experiment $)$ and late $\left(36^{\text {th }}\right.$ and $44^{\text {th }}$ days after the start of the experiment) periods of development of allergic inflammatory process in lung.

The animals were withdrawn from the experiment by overdose of thiopental anesthesia according to the established terms (on the $23^{\text {rd }}, 30^{\text {th }}, 36^{\text {th }}$ and $44^{\text {th }}$ days of the experiment). Pieces of lung were fixed in $10 \%$ neutral buffered formalin solution ( $\mathrm{pH}$ 7.2-7.4). Histological sections were stained with alcyan blue with a critical concentration of $\mathrm{MgCl} 20.2 \mathrm{M}$ to determine the dynamics of mast cell distribution and their morphometric features [8]. A complex of morphometric studies was carried out on a Carl Zeiss Primo Star microscope using the ZEISS ZEN 2011 software. The total number of mucosa related mast cells and perivascular mast cells per unit area of $5000 \mu^{2}$ was counted, using a microscope with oil immersion technique $(\times 1000)$.

The research results were processed by current statistical methods of analysis on a personal computer using the standard software package Microsoft Office 2010 (Microsoft Excel) and STATISTICA $®$ for Windows 6.0 (StatSoft Inc., USA, license 46 No. AXXR712D833214FAN5) based on the Windows 10 operating system. Hypothesis for normal distribution of the studied parameters was checked using the Shapiro-Wilk test and the Kolmogorov-Smirnov test of consistency. The arithmetic means (M) and standard errors of the mean $( \pm \mathrm{m})$ were calculated. The statistical significance of intergroup differences according to the data obtained was established using the parametric Student"s t-test $\left(p^{*}\right)$ and the nonparametric Whitney-Mann U-test $(p * *)$. The obtained data was compared between the median and interquartile range $\mathrm{Me}(\mathrm{Q} 1 ; \mathrm{Q} 3)$. Differences between the compared values at the level of $95 \%(p<0.05)$ were considered statistically significant.

\section{Results}

The morphometric examination of mast cells in the intrapulmonary airways and lung parenchyma of intact guinea pigs has shown that the average number of mucosa related 
mast cells is $2.62 \pm 0.05$, perivascular mast cells $1.38 \pm 0.07$ in the field of view. Normally, in guinea pigs lung, mucosa related mast cells are more abundant, than perivascular mast cells, as evidenced by the increase factor 1.6. We have analysed the number of mast cells in the connective tissue of guinea pigs lung and have found that there was no statistically significant difference between the animals in the intact and control groups that proves that the procedure itself does not affect changes in the number of must cells. Therefore, we compare the results of the experimental and control groups.

OVA - sensitization and challenge leads to quantitative changes in the dynamics of mast cells number of lung connective tissue. The increase in the number of mast cells of both phenotypes is determined in animals of the $1^{\text {st }}$ experimental group from the $23^{\text {rd }}$ day of observation in the early period of development of experimental allergic inflammation, but more significant OVA - challenge effects the number of perivascular mast cells. In addition, further dynamics of changes in their number is different in different experimental groups (Fig. 1).

The maximum average number of mucosa related mast cells, observed in the $1^{\text {st }}$ experimental group, is statistically significantly higher in 1.4 times compare to the animals of the control group $\left(\mathrm{P}^{* / * *}<0.05\right)$. Further investigation has shown that starting from the $30^{\text {th }}$ day of the experiment, there is a tendency for their gradual recovery to the indicators of the control group, reaching the latter on the $44^{\text {th }}$ day of observation.

The average number of perivascular mast cells in animals of the $1^{\text {st }}$ experimental group is by 1.6 times higher compare to the number of mucosa related mast cells, and statistically significantly higher in 3.6 times compare to the control group $\left(P^{* / * *}<0.05\right)$. There is a tendency to increase in the number of perivascular mast cells with the maximum rate on the $44^{\text {th }}$ day of observation, starting from the $36^{\text {th }}$ day of the experiment (Fig. 2).

On the $30^{\text {th }}$ day of observation the average number of mucosa related mast cells is $3.62 \pm 0.05$ in the field of view, which is in 1.3 times more than the same indicator in the control group $\left(P^{* / * *}<0.05\right)$. However, the average number of perivascular mast cells in animals of the $2^{\text {nd }}$ experimental group on the $30^{\text {th }}$ day of observation is in 1.5 times higher than the number of mucosa related mast cells, and statistically significantly higher in 3.5 times compare to the same point in the control group $\left(\mathrm{P}^{* / * *}<0.05\right)$ (Fig. 2).

We have established changes in the dynamics of mast cells of both phenotypes during the late period of development of experimental allergic inflammation in guinea pigs lung. The average number of mucosa related mast cells in the animals of the $3^{\text {rd }}$ experimental group is $3.5 \pm 0.05$ in the field of view, which is statistically significantly in 1.3 times higher $\left(p^{* *}<0.05\right)$, compare to the same indicator of the control group (Fig. 1). The average number of mucosa related mast cells acquires the control indicator on the $44^{\text {th }}$ day of the experiment. The average number of perivascular mast cells in the animals of the $3^{\text {rd }}$ experimental group on the $36^{\text {th }}$ day of observation is in 2 times higher compare to the number of mucosa related mast cells, and statistically significantly higher in 4.5 times compare to the same point in the control

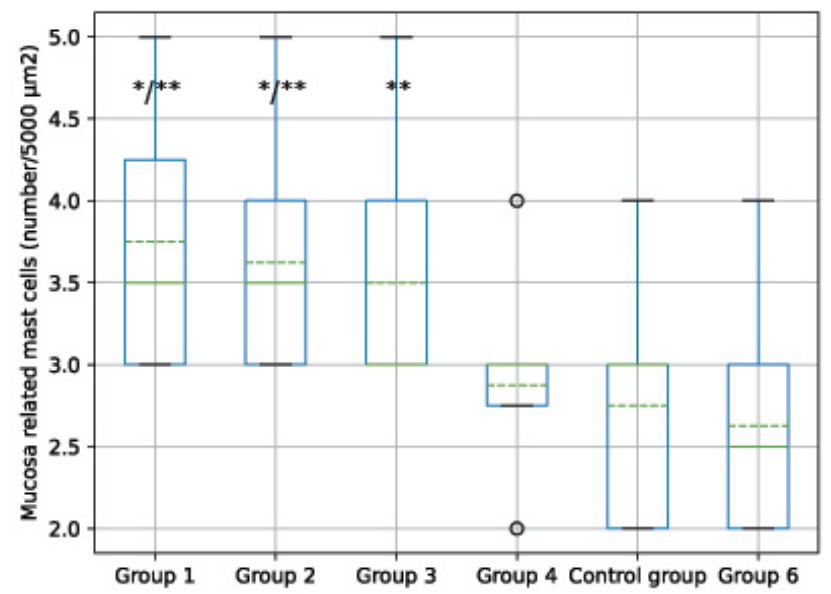

Fig. 1. Morphometric changes in the number of mucosa related mast cells of guinea pigs lung.

Note: * $-P<0.05$ (Student's t-test); ** $-P<0.05$ (Whitney-Mann U-test) compare to the control group. Me (Q1; Q3). The median $(\mathrm{Me})$ is shown by the green line. $M \pm m(n=8)$. The arithmetic mean $(M)$ is shown by the dotted green line. 


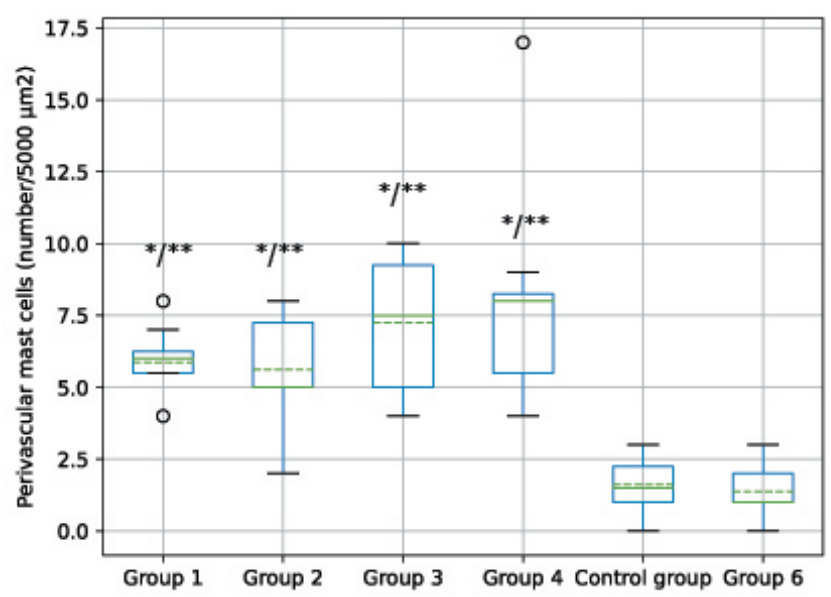

Fig. 2. Morphometric changes in the number of perivascular mast cells in connective tissue of guinea pigs lung parenchyma. Note: * $-P<0.05$ (Student's t-test); ** $-P<0.05$ (Whitney-Mann U-test) compare to the control group. Me (Q1; Q3). The median $(\mathrm{Me})$ - the green line. $M \pm m(n=8)$. The arithmetic mean $(M)$ - the dotted green line.

group $\left(P^{* / * *}<0.05\right)$. The hyperplasia of perivascular mast cells (Fig. 3 ) is found in animals of the $4^{\text {th }}$ experimental group on the $44^{\text {th }}$ day after the start of the experiment $(8.0 \pm 0.29$ in the field of view), which is statistically significantly in 5 times higher than in the control group $\left(\mathrm{P}^{* / * *}<0.05\right)$.

\section{Discussion}

Thus it has been established that in contrast to human and other small mammals (mice), mucosa related must cells are normally more abundant in guinea pigs lung than perivascular ones. Nevertheless, in contrast to BALB/c mice, a common feature of guinea pigs lung connective tissue and human lung in cases of experimental allergic inflammation due to sensitization and challenge with OVA is a statistically significant increase of both mucosa related and perivascular mast cells. However, we have de-

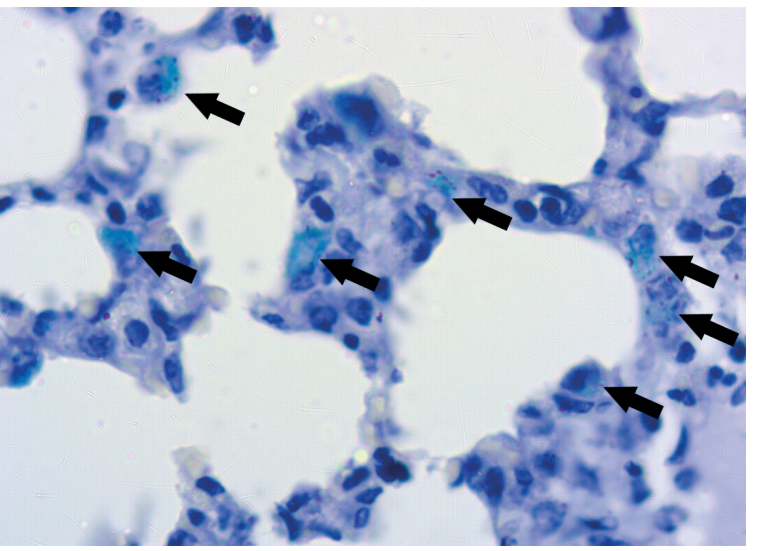

Fig. 3. Perivascular must cells hyperplasia (arrows show) in connective tissue of the pulmonary interstitium of guinea pigs after sensitization and challenge with ovalbumin on the $44^{\text {th }}$ day of the experiment. Staining: alcian blue. $\times 1000$. monstrated that the mast cells number changes of different phenotypes in guinea pigs lung have different nature. Our results revealed the maximum increase in the number of mucosa related mast cells in the early period of development of experimental allergic inflammation, as evidenced by the maximum increase coefficient of 1.4 in the $1^{\text {st }}$ experimental group, compare to the control. It should be noted that the degranulation of mucosa related mast cells promotes the release of heparin, increasing permeability of capillaries and improves trophic of respiratory mucosa. However, the maximum increase in the number of perivascular mast cells in 5 times was evidenced during the late period of allergic inflammatory process development in lung of animals of the $4^{\text {th }}$ experimental group.

Thus, the increase of perivascular mast cells is predominantly greater than mucosa related mast cells in OVA - sensitization. This should be decisive for morphological and histochemical changes of the microcirculatory bed, lymphoid tissue cells in connective tissues of pulmonary interstitium, which were previously described $[7,9]$. For instance, mast cells together with respiratory endocrinocytes help maintain homeostasis of the local lung immune system [10-13]. Moreover, mast cells are involved in both innate and adaptive immune responses to allergens. Due to the presence of heparin secreted by perivascular mast cells into the intercellular substance of connective tissue the permeability of microvessels increases; in allergic inflammation it causes migration of lymphocytes and plasma cells into the perivascular intercellular substance [14-16]. In addition, mast cells contribute to maintenance 
of chronic allergic airway inflammation and are crucial in initiating immune response to the allergen, during which they transmit signals that stimulate IgE synthesis by plasma cells and differentiation of Th2 lymphocytes [17].

\section{Conclusion}

Normally mucosa related mast cells are the predominant mast cell type in guinea pigs lung. OVA - sensitization and challenge leads to the statistically significant increase in the number of both mast cells types: mucosa related and perivascular mast cells.

The dynamics of increase in the number of mast cells of different phenotypes in guinea pigs lung is of a different nature in case of OVAsensitization. More significant is increase in the number of perivascular mast cells in 5 times during the late period of allergic inflammation development in the $4^{\text {th }}$ experimental group.
Despite this the maximum increase in the number of mucosa related mast cells in 1.4 times is established during the early period of experimental allergic inflammation in the $1^{\text {st }}$ experimental group, compare to the control.

\section{Conflict of Interests}

Authors declare no conflict of interest.

\section{Acknowledgements}

This research is a part of the research affairs of Zaporizhzhia State Medical University on "Immunomorphological characteristics of internal organs under the influence of endogenous and exogenous factors on the body", state registration No. $0118 \mathrm{U} 004250$.

\section{Author's Contributions}

Svitlana S. Popko - conceptualization, methodology, formal analysis, investigation, writing - original draft, writing - reviewing and editing; Valentina M. Yevtushenko - data curation, writing - reviewing and editing.

\section{ОСОБЛИВОСТІ РОЗПОДІЛУ І КІЛЬКІСНИХ ЗМІН МАСТОЦИТІВ В ЛЕГЕНЯХ МОРСЬКИХ СВИНОК НА ТЛІ ОВАЛЬБУМІН-ІНДУКОВАНОГО АЛЕРГІЧНОГО ЗАПАЛЕННЯ}

С.С. Попко, В.М. Євтушенко

ЗАПОРІЗЬКИЙ ДЕРЖАВНИЙ МЕДИЧНИЙ УНІВЕРСИТЕТ. ЗАПОРІЖЖЯ, УКРӒ̈НА

Вступ. Одними з найважливіших ключових клітин місцевого імунітету в легенях є мастоцити. Вони беруть участь як у реакціях вродженого, так і адаптивного імунітету у відповідь на інгаляційні алергени. Питання про розподіл обох фенотипів мастоцитів у легенях морської свинки при експериментальному аллергічному запаленні у більшості випадків залишається відкритим.

Мета. Вивчити розподіл та кількісні зміни мастоцитів у легенях морської свинки в умовах овальбумін-індукованого алергічного запалення.

Методи. За допомогою гістологічного, морфометричного, статистичного методів вивчили легені 48 самців морської свинки в умовах експериментального овальбумін-індукованого алергічного запалення. Визначали середню кількість мастоцитів слизових оболонок та навколосудинних мастоцитів улегенях морської свинки.

Результати. Доведено, що в легенях морської свинки в нормі за кількістю переважають мастоцити слизових оболонок, ніж периваскулярні мастоцити. У роботі продемонстрована динаміка зростання вмісту мастоцитів різних фенотипів у легенях морської свинки, яка має різнонаправлений характер в умовах сенсибілізації овальбуміном. Більш суттєвим є приріст саме навколосудинних мастоцитів у 5 азів протягом пізнього періоду розвитку алергічного запального процесу в легенях тварин 4-ої експериментальної групи $\left(P^{* * *}<0.05\right)$, водночас максимальний приріст кількості мастоцитів слизової оболонки дихальних шляхів виявляється протягом раннього періоду розвитку експериментального алергічного запалення, про що свідчить максимальний коефіцієнт збільшення 1,4 в 1-ій експериментальній групі, порівняно з контролем $\left(P^{* * *}<0.05\right)$.

Висновок. Сенсибілізація та аероалергізація овальбуміном призводить до статистично значимого зростання кількості як мастоцитів слизової оболонки дихальних шляхів, так і навколосудинних мастоцитів, з переважанням останніх. Вумовах сенсибілізації овальбуміном динаміка зростання вмісту мастоцитів різних фенотипів у легенях морської свинки має різнонаправлений характер.

КлючовІ СлОВА: мастоцити слизових оболонок, периваскулярні мастоцити, легені, морська свинка, алергічне запалення. 


\section{Information about the authors}

Svitlana S. Popko, PhD, Associate Professor of the Department of Histology, Cytology and Embryology, Zaporizhzhia State Medical University, Zaporizhzhia, Ukraine

ORCID 0000-0002-5533-4556, e-mail: kluchkosv@gmail.com

Valentina M. Yevtushenko, MD, Professor of the Department of Histology, Cytology and Embryology, Zaporizhzhia State Medical University, Zaporizhzhia, Ukraine

ORCID 0000-0002-6858-6488, e-mail: evtushenkovm13@gmail.com

\section{References}

1. Sibilano R, Frossi B, Pucillo CE. Mast cell activation: A complex interplay of positive and negative signaling pathways. European Journal of Immunology. 2014 Aug 22;44(9):2558-66.

DOI: $10.1002 /$ eji.201444546

2. Akdis CA, Arkwright PD, Brüggen $M-C$, Busse W, Gadina M, Guttman-Yassky E, et al. Type 2 immunity in the skin and lungs. Allergy. 2020 May 10;75(7):1582-605.

DOI: $10.1111 /$ all.14318

3. Krystel-Whittemore M, Dileepan KN, Wood JG. Mast Cell: A Multi-Functional Master Cell. Frontiers in Immunology. 2016 Jan 6;6.

DOI: $10.3389 /$ fimmu.2015.00620

4. Bulfone-Paus S, Bahri R. Mast Cells as Regulators of T Cell Responses. Frontiers in Immunology. 2015 Aug 7;6.

DOI: $10.3389 /$ fimmu.2015.00394

5. Méndez-Enríquez E, Hallgren J. Mast Cells and Their Progenitors in Allergic Asthma. Frontiers in Immunology. 2019 May 29;10.

DOI: 10.3389/fimmu.2019.00821

6. Adner M, Canning Brendan J, Meurs H, Ford W, Ramos Ramírez P, van den Berg Mariska PM, et al. Back to the future: re-establishing guinea pig in vivo asthma models. Clinical Science. 2020 Jun;134(11): 1219-42.

DOI: $10.1042 / \operatorname{cs} 20200394$

7. Popko SS. Morphological rearrangement of the metabolic link of the microcirculatory bed of guinea pigs lungs after sensitization with ovalbumin. Current issues in pharmacy and medicine: science and practice. 2021 Mar 18;14(1):79-83.

DOI: 10.14739/2409-2932.2021.1.226851

8. Dey P. Basic and Advanced Laboratory Techniques in Histopathology and Cytology [Internet]. www.springer.com. Springer Singapore; 2018.

Available from: https://www.springer.com/gp/ book/9789811082511

9. Popko SS, Evtushenko VM. Dynamics of the structural elements of guinea pigs bronchi after ovalbumin sensitization. Bulletin of Problems Biology and Medicine. 2021;1(1):240.

DOI: 10.29254/2077-4214-2021-1-159-240-244 [in Ukrainian]
10. Banno A, Reddy Aravind T, Lakshmi Sowmya P, Reddy Raju C. Bidirectional interaction of airway epithelial remodeling and inflammation in asthma. Clinical Science. 2020 May;134(9):1063-79.

DOI: $10.1042 / \operatorname{cs} 20191309$

11. Barrios J, Kho AT, Aven L, Mitchel JA, Park J-A, Randell SH, et al. Pulmonary Neuroendocrine Cells Secrete y-Aminobutyric Acid to Induce Goblet Cell Hyperplasia in Primate Models. American Journal of Respiratory Cell and Molecular Biology. 2019 Jun; 60(6):687-94.

DOI: $10.1165 / \mathrm{rcmb} .2018-01790 \mathrm{c}$

12. Osei ET, Booth S, Hackett T-L. What Have In Vitro Co-Culture Models Taught Us about the Contribution of Epithelial-Mesenchymal Interactions to Airway Inflammation and Remodeling in Asthma? Cells. 2020 Jul 15;9(7):1694.

DOI: $10.3390 /$ cells9071694

13. Popko SS, Evtushenko VM, Syrtsov VK. Influence of pulmonary neuroendocrine cells on lung homeostasis. Zaporozhye Medical Journal. 2020;22(4): 568-75.

DOI: $10.14739 / 2310-1210.4 .208411$

14. Kiboneka A, Kibuule D. The Immunology of Asthma and Allergic Rhinitis. Rhinosinusitis. 2019 Dec 4.

Available from: https://doi.org/10.5772/ intechopen.86964

15. Klose CSN, Artis D. Innate lymphoid cells as regulators of immunity, inflammation and tissue homeostasis. Nature Immunology. 2016 Jun 21; 17(7):765-74.

DOI: $10.1038 /$ ni.3489

16. Molofsky Ari B, Savage Adam K, Locksley Richard M. Interleukin-33 in Tissue Homeostasis, Injury, and Inflammation. Immunity. 2015 Jun;42(6): 1005-19.

DOI: 10.1016/j.immuni.2015.06.006

17. Richards CD, Botelho F. Oncostatin M in the Regulation of Connective Tissue Cells and Macrophages in Pulmonary Disease. Biomedicines. 2019 Dec 5;7(4):95.

DOI: 10.3390/biomedicines7040095

Received 12 Apr 2021; revised 22 Apr 2021; accepted 23 Apr 2021.

This is open access article distributed under the Creative Commons Attribution License, which permits unrestricted use, distribution, and reproduction in any medium, provided the original work is properly cited. 